\title{
Interaksi Antarwilayah dan Sebaran Covid-19 di Provinsi Kalimantan Barat
}

\author{
Regions Interaction and Covid-19 Spread in West Kalimantan
}

\author{
Syaiful Muazir ${ }^{1}$ \\ Program Studi Arsitektur, Fakultas Teknik, Universitas Tanjungpura, Pontianak, Indonesia
}

\section{Lestari}

Program Studi Arsitektur, Fakultas Teknik, Universitas Tanjungpura, Pontianak, Indonesia

\section{Muhammad Ridha Alhamdani}

Program Studi Arsitektur, Fakultas Teknik, Universitas Tanjungpura, Pontianak, Indonesia

\author{
Muhammad Nurhamsyah \\ Program Studi Arsitektur, Fakultas Teknik, Universitas Tanjungpura, Pontianak, Indonesia
}

Artikel Masuk : 1 Juli 2020

Artikel Diterima : 8 Februari 2021

Tersedia Online : 30 April 2021

\begin{abstract}
Abstrak: Covid-19 adalah penyakit yang menyerang saluran pernafasan yang mulai diidentifikasi terjadi di wilayah Wuhan, Provinsi Hubei, Cina. Organisasi kesehatan dunia (WHO) kemudian mengumumkan penyakit tersebut sebagai penyakit pandemi yang cepat menyebar ke seluruh dunia. Penyebaran Pandemi Coronavirus (COVID-19) yang sangat cepat juga terjadi di Kalimantan Barat (Kalbar), Indonesia. Dalam perspektif spasial-temporal, penyebaran penyakit infeksi (endemi/pandemi) dapat terjadi karena adanya interkonektivitas atau interaksi antarwilayah, populasi, serta fasilitas transportasi yang memudahkan mobilitas masyarakat. Penelitian ini bertujuan untuk menggambarkan interaksi antarwilayah di Kalimantan Barat dan kaitannya dengan penyebaran pandemik Covid-19. Metode yang digunakan adalah dengan menggunakan perhitungan sentralitas dan klaster. Hasil dari perhitungan tersebut kemudian dideskripsikan kecenderungannya dengan sebaran kasus Covid-19 di Kalbar. Berdasarkan hasil justifikasi, wilayah-wilayah dengan sentralitas tinggi dalam konfigurasi jaringan di Kalbar cenderung mempunyai kasus terkonfirmasi terbanyak dibandingkan dengan wilayah lain. Karakter wilayah-wilayah tersebut cenderung merupakan pintu masuk utama (udara/pelabuhan), Ibukota provinsi, serta wilayah hub di Kalbar yang juga merupakan dalam satu kesatuan klaster. Hal yang menarik lainnya adalah wilayahwilayah dengan nilai rendah dalam sentralitasnya, serta masuk dalam klaster yang sama mempunyai jumlah orang dalam pantauan (ODP) yang cukup besar dibandingkan dengan klaster sebelumnya. Wilayah-wilayah ini cenderung mempunyai populasi yang padat serta berhubungan langsung dengan Ibukota Provinsi dan negara tetangga (perbatasan).
\end{abstract}

Kata Kunci: Covid-19; Kalimantan Barat; interaksi; wilayah

\footnotetext{
${ }^{1}$ Korespondensi Penulis: Program Studi Arsitektur, Fakultas Teknik, Universitas Tanjungpura, Pontianak, Indonesia Email: syaifulmuazir@gmail.com/syaifulmuazir@teknik.untan.ac.id
} 


\title{
19 Interaksi Antarwilayah dan Sebaran Covid-19 di Provinsi Kalimantan Barat
}

\begin{abstract}
Covid-19 is a disease that attacks the respiratory tract that began to be identified in Wuhan, China. WHO then announced the condition as a pandemic that quickly spread throughout the world. The rapid spread of the Coronavirus Pandemic (COVID-19) also occurred in West Kalimantan, Indonesia. In a spatial-temporal perspective, the spread of infectious diseases can be happened by the interconnectivity or interaction between areas, populations, and transportation facilities that facilitate community mobility. This research aims to describe the interactions between regions in West Kalimantan and the relation to the spread of the Covid-19 pandemic. The method used centrality measurement and cluster analysis, where the results of these calculations are then described in line with the distribution of the Covid-19 case in West Kalimantan. From the justification, areas with high centrality in the network configuration tend to have the most confirmed cases compared to other areas. The character of these areas tends to be the main entrance (air/port), the provincial capital, and the hub area in West Kalimantan, which is also included as the same cluster. Another interesting finding is that areas with low centrality, and included in the same cluster, have several people under surveillance which is quite large compared to the previous cluster. These areas tend to have a dense population and are directly related to the Provincial Capital and neighboring countries (border).
\end{abstract}

Keywords: areas; Covid-19; West Kalimantan; interaction

\section{Pendahuluan}

Pada akhir tahun 2019 sebuah penyakit yang menyerang saluran pernafasan mulai diidentifikasi terjadi di wilayah Wuhan, Provinsi Hubei, Cina. Penyakit ini disebabkan oleh virus corona jenis baru yang memiliki kedekatan dengan virus corona. Organisasi kesehatan dunia (WHO) kemudian mengumumkan penyakit tersebut sebagai penyakit corona virus 2019 atau Coronavirus Disease (COVID-19). Penyakit ini dengan cepat menyebar ke beberapa wilayah lain sejak pertama kali diidentifikasi termasuk Hong Kong, Makau, dan Taiwan (Wang et al., 2020). Kasus penyakit tersebut menjadi masalah kesehatan secara global (Wang et al., 2020), karena penyebarannya juga terjadi di negara lain, bahkan ke lebih dari 30 negara dalam waktu dua bulan (Zhao \& Chen, 2020). Covid-19 memiliki gejala, karakteristik dan cara penyebaran yang mulai diidentifikasi melalui beberapa penelitian. Kondisi demam, batuk dan kelelahan merupakan gejala yang paling dominan ditemukan (Guan et al., 2020; Huang et al., 2020). Gejala parah dan berisiko fatal terjadi pada penyakit ini berupa gangguan pada pernafasan (Chen et al., 2020). Penularan Covid 19 diyakini terjadi dari manusia ke manusia (Li et al., 2020), namun cara penyebarannya masih terus dipelajari sampai saat ini.

Terkait dengan penyebaran penyakit infeksi (pandemi/endemi), beberapa diskusi dan pembahasan dalam penelitian sebelumnya memberikan gambaran bahwa penyebaran penyakit lebih cepat terjadi pada kondisi, di antaranya: (1) kawasan metropolitan dengan jumlah populasi yang besar (Inaida et al., 2011), (2) hierarki perkotaan dan heterogenitas populasi (Merler \& Ajelli, 2010), (3) mobilitas masyarakat (Bajardi et al., 2011), (4) kemudahan transportasi (Lawyer, 2016), dan (5) kemudahan interkoneksivitas antardaerah (Grais et al., 2003; Tuncer \& Le, 2014). Kang et al. (2020) menyebutkan bahwa penyebaran Covid-19 dari Wuhan didukung oleh terhubungnya jaringan transportasi (kereta dan bis) ke daerah lain serta terhubungnya transportasi udara secara masif dari China (Lau et al., 2020). Selain itu, infeksinya juga teridentifikasi tersebar dari daerah yang padat penduduk ke daerah yang tidak pada penduduk terutama pada area-area publik yang cenderung adanya interaksi masyarakat (Kadi \& Khelfaoui, 2020). Kubota et al. (2020) dan Xie et al. (2020) menjelaskan bahwa mobilitas dan pergerakan masyarakat dari perbatasan wilayah masing-masing juga mendukung infeksi Covid-19. Selain itu, pertimbangan pergerakan masyarakat pada wilayah-wilayah maju (perekonomian) juga dapat menjadi faktor penyebaran Covid-19. 
Dalam kaitannya dengan keterhubungan antarwilayah dan mobilitas yang terjadi, hubungan (interaksi) antarwilayah pada dasarnya sangat dibutuhkan untuk saling melengkapi kebutuhan dasar yang mencakup arus modal, keuangan, barang dan jasa, serta pengeluaran pemerintah. Untuk berinteraksi antardaerah serta berbagi aliran barang dan jasa, sebuah daerah hendaknya berhubungan (koneksi) antara satu dengan yang lainnya. Konektivitas dapat diartikan sebagai kemudahan perpindahan dari satu lokasi ke lokasi lainnya antarmanusia, material, atau informasi (Sokol, 2009). Glasson \& Marshall (2007) menjelaskan bahwa konektivitas menjadi bagian yang sangat penting dalam memfasilitasi terjadinya interaksi antardaerah. Melalui konektivitas, akan dapat mendorong dan menghasilkan hubungan antarmanusia, barang, dan daerah (Staeheli, 2012), sebagaimana juga akan berdampak secara langsung dalam aliran usaha-usaha (Lobo-Guerrero, 2012) dan meningkatkan pertumbuhan ekonomi (Vega, 2012).

Penyebaran Pandemi Coronavirus (COVID-19) yang sangat cepat juga terjadi di Indonesia. Kasus positif pertama di Indonesia terdeteksi pada tanggal 2 Maret 2020, ketika dua orang terkonfirmasi tertular dari seorang warga negara Jepang (Ratcliffe, 2020). Berselang hanya sebulan lebih dari kasus pertama, pada tanggal 9 April pandemi Covid-19 sudah menyebar ke 34 provinsi di Indonesia dengan Jawa Timur, DKI Jakarta, dan Sulawesi Selatan sebagai provinsi paling terpapar (Reuters, 2020). Pemerintah pusat dalam mengantisipasi pandemi ini membentuk Gugus tugas percepatan penanganan Covid-19. Kebijakan lain yang diambil pemerintah pusat melalui daerah dalam menanggulangi penyebaran covid ini yaitu dengan menerapkan Pembatasan Sosial Berskala Besar (PSBB) atau pembatasan kegiatan tertentu dalam suatu wilayah yang diduga terinfeksi virus corona atau COVID-19.

Di Kalimantan Barat (Kalbar) sendiri, siaga perkembangan wabah Covid-19 di Kalbar dimulai dengan dikeluarkannya Surat Edaran Kejadian Luar Biasa (KLB) tentang tanggap darurat Corona Virus 2019 tanggal 17 Maret 2020 oleh Gubernur Kalbar yang terdata sebanyak 110 orang dalam pemantauan dan 15 orang dalam pengawasan yang tersebar dalam beberapa kabupaten di Kalbar. Sebelumnya, titik awal deteksi pada tanggal 2 Februari 2020 berupa satu orang pasien dalam pemantauan (PDP). Kasus awal pasien terkonfirmasi positif muncul di Kalbar mulai pertengahan Maret, yaitu satu orang di Kota Pontianak (RSUD. Dr.Soedarso) dan satu orang di Singkawang (RSUD Abdul Aziz). Sejauh ini, perkembangan wabah Covid-19 mencapai penambahan tertinggi dalam satu harinya pada tangal 23 Mei 2020 sebanyak 27 orang yang terkonfirmasi positif dan hingga saat ini perkembangannya cenderung menurun yaitu per 30 Juni 2020 hanya berjumlah satu orang dengan status PDP (Pemerintah Provinsi Kalimantan Barat, 2020). Berbagai macam kebijakan telah dilakukan oleh Pemerintah Provinsi Kalimantan Barat untuk meredam sebaran wabah Covid-19, termasuk antisipasi penyebaran pada daerah perbatasan secara langsung dari luar negeri (Kuching dan Brunei Darussalam) dan dengan provinsi lainnya seperti Kalimantan Tengah.

Melihat bagaimana penyakit infeksi (endemi/pandemi) menyebar dalam perspektif adanya mobilitas (pergerakan) masyarakat dan adanya fasilitas (transportasi), serta keterhubungan antarwilayah yang mendukung, studi mengenai interaksi antarwilayah dapat dilakukan untuk melihat kecenderungan hubungan antarwilayah serta kaitannya dengan karakter wilayah (daerah) yang terdampak. Dalam pengertian umum, interaksi dapat diartikan sebagai pertukaran, tetapi bisa saja tanpa mengubah satu dengan yang lainnya (Edmonds, 2007). Untuk dapat berinteraksi, wilayah-wilayah hendaknya berhubungan (terkoneksi), dalam pengertian adanya kemudahan perpindahan lokasi, dari satu lokasi ke lokasi lainnya dari manusia, material, atau informasi yang sering disebut konektivitas (Sokol, 2009). Dalam perhitungannya, konektivitas mempunyai hubungan yang erat dengan konsep analisis jaringan yang terbentuk atas node (titik/simpul) dan link (penghubung/tautan) yang masing-masing dapat memberikan nilai bagi keterhubungan 


\section{Interaksi Antarwilayah dan Sebaran Covid-19 di Provinsi Kalimantan Barat}

antarwilayah (Sokol, 2009). Downs \& Horner (2012) menjelaskan ilustrasi grafik dan pendekatan analisis jaringan (network analysis) dapat digunakan untuk menganalisis hubungan antar lokasi dalam bentuk titik (node/vertices) dan penghubungnya (link/edge). Diadopsi dari Borgatti et al. (2013) dalam buku yang berjudul Analyzing Social Networks setidaknya terdapat tiga pendekatan dasar dalam analisis jaringan yang dapat digunakan untuk melakukan perhitungan dan melihat kecenderungan di dalam sebuah jaringan. Pendekatan-pendekatan tersebut adalah: (1) keterpusatan atau sentralitas (centrality); (2) sub grafik atau kelompok (subgraph); dan (3) persamaan derajat (equivalence). Borgatti et al. (2013) menjelaskan bahwa keterpusatan (centrality) adalah pendekatan penting yang mencoba untuk mencari titik paling krusial di dalam sebuah jaringan, subgraph (sub grafik) atau subgroup adalah beberapa aktor atau titik yang saling berhubungan antara satu dengan lainnya dan dapat dipertimbangkan menjadi entitas independen dan structural equivalence yang merupakan bentuk hubungan langsung antara aktor/titik kepada aktor/titik lainnya.

Berdasarkan beberapa deskripsi tersebut, permasalahan yang timbul dari beberapa latar belakang yang dibahas pada penelitian ini adalah untuk dapat memberikan gambaran mengenai hubungan antara interaksi wilayah dengan sebaran kasus Covid-19, khususnya di Kalbar. Dari beberapa penelitian sebelumnya, interaksi antarwilayah dalam konteks hierarki dan kemudahan mobilitas menjadi hal yang terpenting dalam mendukung pengembangan wilayah. Namun di lain pihak, kemudahan - kemudahan tersebut juga menjadi indikator kemudahan penyebaran penyakit khususnya pandemi maupun endemi. Berdasarkan latar belakang dan permasalahan yang diutarakan, penelitian ini bertujuan untuk menggambarkan interaksi antarwilayah di Kalimantan Barat dan kaitannya dengan penyebaran pandemik Covid-19. Secara umum, deskripsi kecenderungan sebaran Covid-19 di Kalimantan Barat disampaikan dalam skala waktu, dan selanjutnya akan ditumpangtindihkan dengan karakter interaksi antarwilayah melalui analisis jaringan yang menghasilkan beberapa kecederungan posisi masing-masing wilayah. Luaran dari penelitian ini diharapkan memberikan kontribusi (kebaruan) bagi keilmuan pengembangan wilayah (analisis jaringan) terkait pertimbangan interaksi wilayah dalam konteks pengembangan dan dampaknya terhadap penyebaran penyakit.

\section{Metode Penelitian}

Penelitian ini merupakan penelitian yang menggunakan pendekatan analisis jaringan atau Network Analysis, yang digunakan untuk menganalisis hubungan antar lokasi dalam bentuk titik (node/vertices) dan penghubungnya (link/edge). Sebagaimana dijelaskan oleh Borgatti et al. (2013), setidaknya terdapat tiga pendekatan dasar dalam analisis jaringan yang dapat digunakan untuk melakukan perhitungan dan melihat kecederungan yang ada di dalam sebuah jaringan. Pendekatan-pendekatan tersebut adalah: (1) keterpusatan atau sentralitas (centrality), (2) sub grafik atau kelompok (subgraph), dan (3) persamaan derajat (equivalence). Dari masing-masing pendekatan, juga masih terdapat beberapa detail perhitungan yang dapat dilakukan, seperti dengan in/out degree, closeness, betweenness, eigenvector, clique, blockmodels, effective, efficient dan lain sebagainya. Setelah didapatkan kecenderungan jaringan yang ada, hasil didiskusikan terhadap perkembangan penyebaran kasus-kasus Covid-19 di wilayah Kalbar. Dalam pemaparan hasil penelitian ini, terdapat tiga tahapan yang dilakukan, pertama yaitu pengumpulan data mingguan jumlah terpapar Covid-19 di Provinsi Kalimantan Barat (Kalbar), serta data interaksi wilayah di Kalbar (incoming/outgoing). Data interaksi yang digunakan adalah jaringan fasilitas transportasi yang berupa keterhubungan melalui darat (jalan), udara, dan perairan di Kalbar. Pengumpulan data dikumpulkan melalui sumber sebaran dan perkembangan Covid-19 dari Dinas Kesehatan Provinsi Kalimantan Barat (2020), serta data-data sekunder 
yang memberikan informasi mengenai jalur-jalur transportasi yang ada di Kalbar seperti jalur jalan, jalur penerbangan, dan jalur pelayaran (Pelabuhan) utama. Kedua, analisis jaringan yang akan menganalisis dan mendeskripsikan keterpusatan atau sentralitas (centrality), serta kelompok atau klaster (subgraph) wilayah yang saling berhubungan di Kalbar. Ketiga, memaparkan hasil-hasil keterpusatan dan klaster interaksi wilayah di Kalbar dan membahas hubungannya terhadap penyebaran Covid-19 di Kalbar. Pembahasan dilakukan dengan mendiskusikan kecenderungan arah interaksi wilayah serta banyaknya kasus-kasus yang ada seperti yang telah terkonfirmasi (positif), orang dalam pantauan (ODP) dan PDP di masing-masing wilayah dalam perspektif sentralitas dan klaster. Lokasi Penelitian di Kalimantan Barat ditampilkan pada Gambar 1.

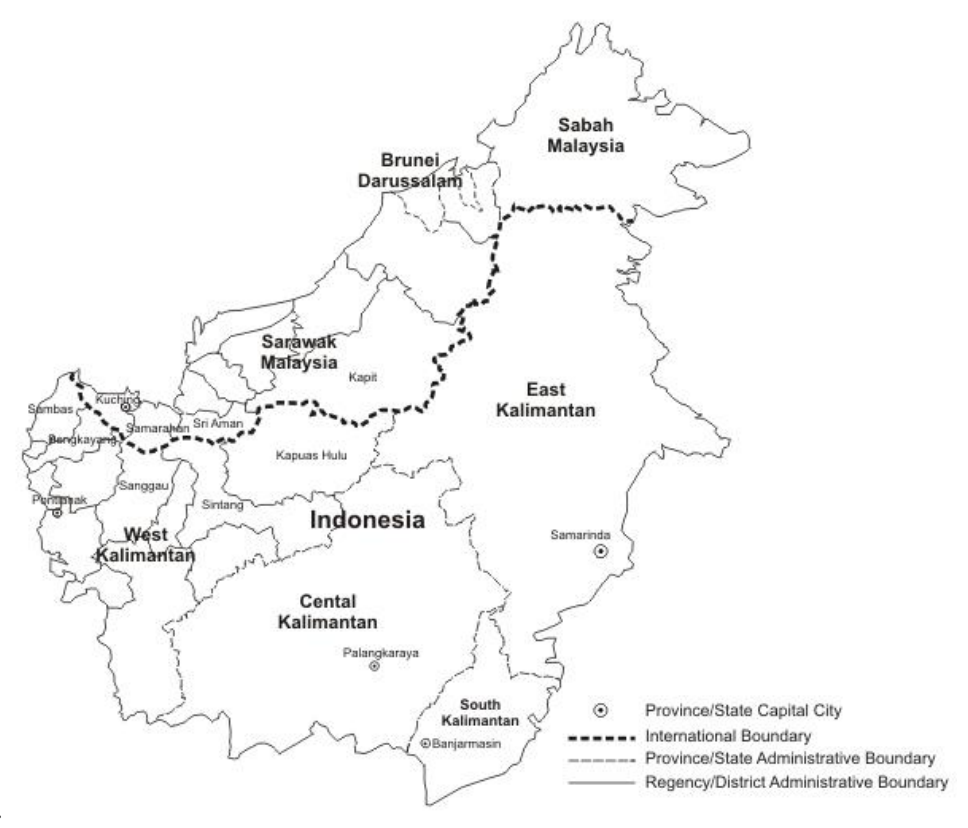

Gambar 1. Provinsi Kalimantan Barat di dalam Pulau Kalimantan

\section{Hasil dan Pembahasan}

\section{Interaksi Wilayah di Kalimantan Barat}

Pada bagian ini, masing-masing wilayah di Kalbar dideskripsikan sesuai dengan interaksi dan kemungkinan/kemudahan mobilitas yang ada. Masing-masing wilayah yang terhubung baik di darat, laut, dan udara melalui fasilitas transportasi dihubungkan antara satu dengan yang lain. Berdasarkan pada beberapa sumber data yang telah dikumpulkan (geospasial Kalbar, kataomed, dan angkasapura), pada Tabel 1 merupakan daftar interaksi antarwilayah di Kalbar. Beberapa data yang dikumpulkan dapat dilihat dalam Gambar 2 tentang bagaimana jaringan yang ada di Kalbar saling berhubungan. Dari Gambar 2, secara visual dapat dilihat area/wilayah yang berinteraksi tinggi (dengan banyaknya garis yang berhubungan) seperti Kubu Raya, Sanggau, Sarawak, dan lain-lain atau wilayah dengan interaksi rendah seperti Nanga Bulik, Kayong Utara, Batam, dan lain-lain.

\section{Analisis Jaringan di Kalimantan Barat}

Analisis jaringan di Kalbar dilakukan dengan beberapa detail perhitungan sesuai dengan pendekatan penelitian yang digunakan, yaitu keterpusatan suatu wilayah atau 
sentralitas (centrality), serta kelompok atau klaster (subgraph) wilayah yang saling berhubungan di Kalbar. Pada perhitungan, digunakan perangkat lunak analisis jaringan UCINET (Borgatti et al., 2002). Dalam perhitungan centrality, beberapa detail perhitungan yang dilakukan adalah: (1) degree, (2) closeness, (3) betweenness, (4) eigenvector.

Tabel 1. Interaksi Antarwilayah di Kalimantan Barat

\begin{tabular}{|c|c|c|c|c|c|c|c|c|}
\hline No & Asal & Tujuan & No & Asal & Tujuan & No & Asal & Tujuan \\
\hline 1 & Pontianak & Kubu Raya & 24 & Sanggau & Landak & 47 & Ketapang & $\begin{array}{l}\text { Kayong } \\
\text { Utara }\end{array}$ \\
\hline 2 & Pontianak & Mempawah & 25 & Sanggau & Kubu Raya & 48 & $\begin{array}{l}\text { Kayong } \\
\text { Utara }\end{array}$ & Ketapang \\
\hline 3 & Kubu Raya & Sanggau & 26 & Sanggau & Sekadau & 49 & Kubu Raya & Sintang \\
\hline 4 & Kubu Raya & Pontianak & 27 & Sanggau & Sarawak & 50 & Kubu Raya & $\begin{array}{l}\text { Kapuas } \\
\text { Hulu }\end{array}$ \\
\hline 5 & Mempawah & Pontianak & 28 & Sanggau & Ketapang & 51 & Kubu Raya & Ketapang \\
\hline 6 & Mempawah & Landak & 29 & Ketapang & Sanggau & 52 & Kubu Raya & Sarawak \\
\hline 7 & Mempawah & Singkawang & 30 & Ketapang & $\begin{array}{l}\text { Nanga } \\
\text { Bulik }\end{array}$ & 53 & Kubu Raya & Jakarta \\
\hline 8 & Mempawah & Bengkayang & 31 & $\begin{array}{l}\text { Nanga } \\
\text { Bulik }\end{array}$ & Ketapang & 54 & Kubu Raya & Surabaya \\
\hline 9 & Singkawang & Mempawah & 32 & Sintang & Sanggau & 55 & Kubu Raya & Semarang \\
\hline 10 & Singkawang & Bengkayang & 33 & Sintang & Sekadau & 56 & Kubu Raya & Batam \\
\hline 11 & Singkawang & Sambas & 34 & Sintang & Melawi & 57 & Kubu Raya & Yogyakarta \\
\hline 12 & Landak & Mempawah & 35 & Sintang & Sarawak & 58 & Kubu Raya & Makassar \\
\hline 13 & Landak & Bengkayang & 36 & Sintang & $\begin{array}{l}\text { Kapuas } \\
\text { Hulu }\end{array}$ & 59 & Sintang & Kubu Raya \\
\hline 14 & Landak & Sanggau & 37 & Sekadau & Sanggau & 60 & $\begin{array}{l}\text { Kapuas } \\
\text { Hulu }\end{array}$ & Kubu Raya \\
\hline 15 & Bengkayang & Landak & 38 & Sekadau & Sintang & 61 & Ketapang & Kubu Raya \\
\hline 16 & Bengkayang & Mempawah & 39 & Melawi & Sintang & 62 & Sarawak & Kubu Raya \\
\hline 17 & Bengkayang & Singkawang & 40 & $\begin{array}{l}\text { Kapuas } \\
\text { Hulu }\end{array}$ & Sintang & 63 & Jakarta & Kubu Raya \\
\hline 18 & Bengkayang & Sambas & 41 & $\begin{array}{l}\text { Kapuas } \\
\text { Hulu }\end{array}$ & Sarawak & 64 & Surabaya & Kubu Raya \\
\hline 19 & Bengkayang & Sarawak & 42 & Sarawak & Sambas & 65 & Semarang & Kubu Raya \\
\hline 20 & Sambas & Singkawang & 43 & Sarawak & Bengkayang & 66 & Batam & Kubu Raya \\
\hline 21 & Sambas & Bengkayang & 44 & Sarawak & Sanggau & 67 & Yogyakarta & Kubu Raya \\
\hline 22 & Sambas & Sarawak & 45 & Sarawak & Sintang & 68 & Makassar & Kubu Raya \\
\hline \multirow[t]{2}{*}{23} & Sanggau & Sintang & 46 & Sarawak & $\begin{array}{l}\text { Kapuas } \\
\text { Hulu }\end{array}$ & 69 & Pontianak & Semarang \\
\hline & & & & & & 70 & Semarang & Pontianak \\
\hline
\end{tabular}

Berdasarkan hasil simulasi/analisis jaringan atau interaksi wilayah untuk sentralitas yang ada di Kalbar, dapat dilihat dari empat macam perhitungan yang ada, yaitu (1) degree, (2) closeness, (3) betweenness, (4) eigenvector. Secara definisi, degree adalah jumlah garis (tautan) yang berhubungan dengan satu titik (Borgatti et al., 2013; Scott et al., 2008). Closeness mencerminkan seberapa dekat para aktor/titik mencapai yang lain, satu titik menjadi sentral jika dapat berinteraksi dengan cepat dengan titik lainnya (Wasserman \& Faust, 1994). Betweenness adalah aktor/titik yang berada di tengah, titik di antara yang lain, titik yang menjembatani dan pengontrol aliran dalam jaringan (Borgatti et al., 2013; Wasserman \& Faust, 1994), dan eigenvector adalah upaya untuk menemukan aktor/titik paling sentral dalam hal struktur jaringan secara keseluruhan (Borgatti, 1995; Borgatti et al., 2013; Hanneman \& Riddle, 2005). Adapun rumus masing-masing perhitungan ditampilkan pada Tabel 3. 


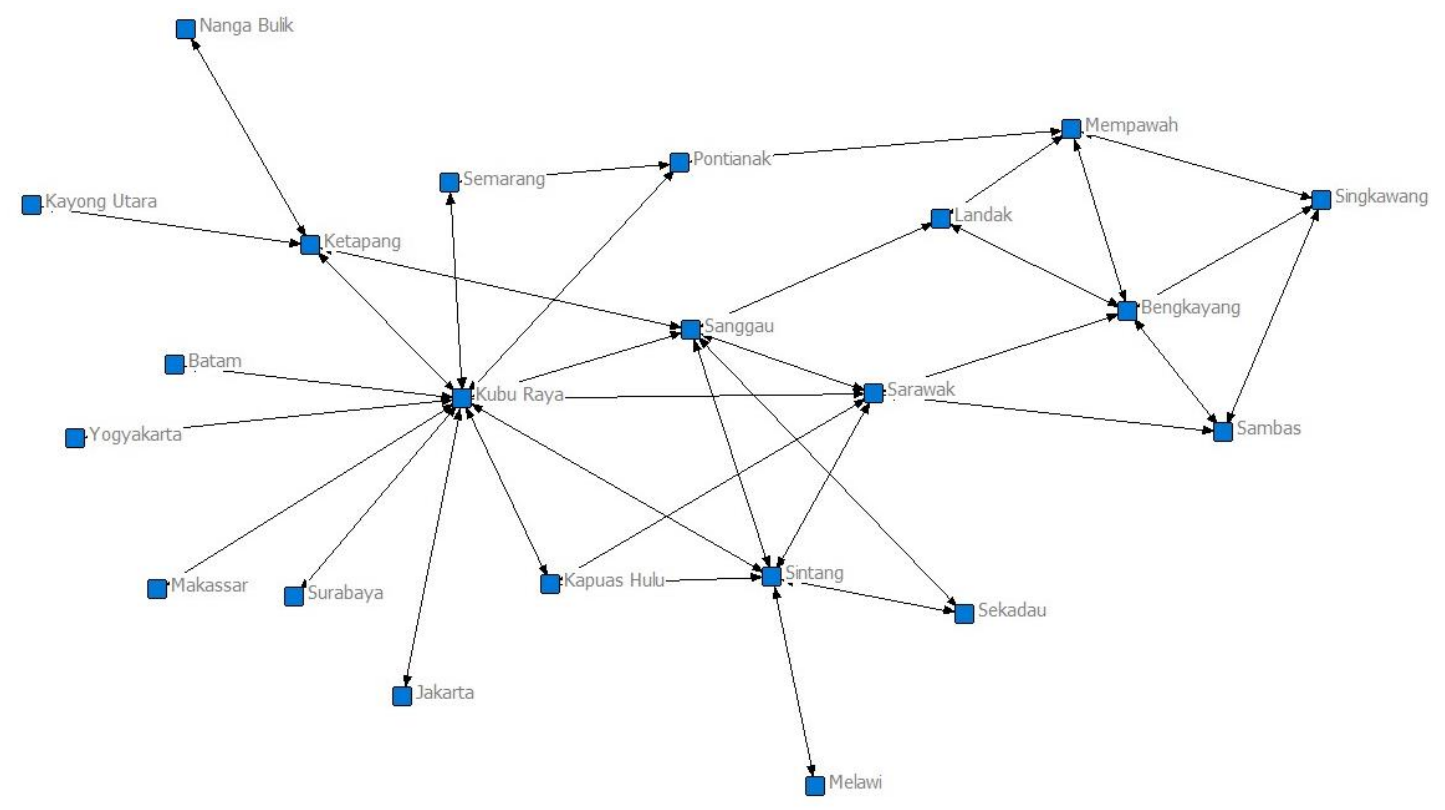

Gambar 2. Jaringan/Interaksi Antarwilayah di Kalimantan Barat

Tabel 2. Perhitungan Sentralitas Wilayah di Kalbar

\begin{tabular}{clrrrr}
\hline No & \multicolumn{1}{c}{ Area } & Degree & \multicolumn{1}{c}{ Closeness } & Betweenness & Eigenvector \\
\hline 1 & Batam & 4,762 & 41,176 & 0,000 & 14,907 \\
2 & Bengkayang & $\mathbf{2 3 , 8 1 0}$ & 42,000 & 5,493 & 25,830 \\
3 & Jakarta & 4,762 & 41,176 & 0,000 & 14,907 \\
4 & Kapuas Hulu & 14,286 & $\mathbf{4 7 , 7 2 7}$ & 0,000 & 37,005 \\
5 & Kayong Utara & 4,762 & 32,813 & 0,000 & 5,916 \\
6 & Ketapang & 19,048 & 47,727 & $\mathbf{1 8 , 5 7 1}$ & 28,212 \\
7 & Kubu Raya & $\mathbf{5 7 , 1 4 3}$ & $\mathbf{6 7 , 7 4 2}$ & $\mathbf{5 9 , 4 6 1}$ & $\mathbf{7 1 , 0 8 7}$ \\
8 & Landak & 14,286 & 42,857 & 3,662 & 19,816 \\
9 & Makassar & 4,762 & 41,176 & 0,000 & 14,907 \\
10 & Melawi & 4,762 & 35,000 & 0,000 & 10,816 \\
11 & Mempawah & 19,048 & 39,623 & 4,495 & 17,052 \\
12 & Nanga Bulik & 4,762 & 32,813 & 0,000 & 5,916 \\
13 & Pontianak & 14,286 & $\mathbf{4 7 , 7 2 7}$ & 6,712 & 22,603 \\
14 & Sambas & 14,286 & 39,623 & 2,591 & 19,439 \\
15 & Sanggau & $\mathbf{2 8 , 5 7 1}$ & $\mathbf{5 6 , 7 5 7}$ & $\mathbf{1 7 , 1 2 6}$ & $\mathbf{5 1 , 6 1 4}$ \\
16 & Sarawak & $\mathbf{2 8 , 5 7 1}$ & $\mathbf{5 5 , 2 6 3}$ & $\mathbf{1 8 , 9 9 1}$ & $\mathbf{5 3 , 8 0 0}$ \\
17 & Sekadau & 9,524 & 38,889 & 0,000 & 21,640 \\
18 & Semarang & 9,524 & 43,750 & 0,000 & 19,647 \\
19 & Singkawang & 14,286 & 31,818 & 0,397 & 13,069 \\
20 & Sintang & $\mathbf{2 8 , 5 7 1}$ & $\mathbf{5 2 , 5 0 0}$ & $\mathbf{1 2 , 9 7 6}$ & $\mathbf{5 1 , 5 7 8}$ \\
21 & Surabaya & 4,762 & 41,176 & 0,000 & 14,907 \\
22 & Yogyakarta & 4,762 & 41,176 & 0,000 & 14,907 \\
\hline & & & & &
\end{tabular}


Tabel 3. Rumus Perhitungan Sentralitas

\begin{tabular}{cc}
\hline In/Out Degree & Closeness \\
\hline$k_{i}^{\text {out }}=\sum_{j} a_{i j} k_{i}^{\text {in }}=\sum_{j} a_{j i}$ & $C_{C}\left(n_{i}\right)=\left[\sum_{j=1}^{g} d\left(n_{i}, n_{j}\right)\right]^{-1} \cdot$ \\
\hline Betweenness & Eigenvector \\
\hline$C_{B}\left(n_{i}\right)=\sum_{j<k} g_{j k}\left(n_{i}\right) / g_{j k}$ & $e_{i}=\lambda^{-1} \sum_{j} a_{i j} e_{j}$
\end{tabular}

Sumber: Borgatti, 1995; Borgatti et al., 2013; Scott et al., 2008; Wasserman \& Faust, 1994

Berdasarkan Tabel 2, dapat dilihat secara umum Kabupaten Kubu Raya merupakan wilayah dengan nilai (skor) tertinggi dalam masing-masing kategori perhitungan. Untuk degree, Kubu Raya, Sarawak, Sanggau, Sintang menjadi wilayah-wilayah yang paling banyak terhubung dengan wilayah lain. Selanjutnya diikuti oleh Bengkayang dan lain-lain. Untuk closeness, secara runut Kubu Raya, Sanggau, Sarawak, Sintang, Ketapang, dan Kapuas Hulu masing-masing mempunyai nilai yang tinggi dibandingkan dengan wilayah lainnya. Hal ini mengindikasikan bahwa masing-masing wilayah merupakan wilayah yang paling cepat untuk mendekati wilayah lainnya dalam konfigurasi jaringan yang ada. Untuk betweenness masing-masing Kubu Raya, Sarawak, Ketapang, Sanggau, dan Sintang mempunyai rata-rata nilai yang cukup tinggi dibandingkan dengan wilayah lain. Hal ini dapat diindikasikan bahwa wilayah-wilayah tersebut mempunyai daya jangkau yang efektif untuk menjangkau wilayah-wilayah lainnya dan menjadi titik tengah (hub) bagi wilayah lainnya. Untuk eigenvector atau wilayah utama, dapat dilihat dalam bahwa wilayah-wilayah seperti Kubu Raya, Sarawak, Sintang, dan Sanggau, merupakan beberapa wilayah sentral dalam konfigurasi jaringan yang ada di Kalbar.

Berdasarkan Gambar 2, dapat dilihat bahwa Kabupaten Kubu Raya yang berdekatan dengan Ibukota Provinsi atau Kota Pontianak menjadi salah satu wilayah yang penting dalam sistem interaksi antarwilayah yang ada di Kalbar. Hal ini dapat dilihat bagaimana Kabupaten Kubu Raya (Kubu Raya) mempunyai banyak interaksi/hubungan dengan wilayah luar di Kalbar, karena di Kubu Raya memiliki Bandara Internasional Supadio. Selain itu, Kubu Raya juga merupakan Kabupaten yang berbatasan langsung dengan Kota Pontianak yang berjarak hanya sekitar $50 \mathrm{Km}$ dari pusat kota. Kubu Raya menjadi salah satu daerah penyanggah Kota Pontianak, karena dekatnya jarak ke Kota Pontianak. Pembangunan di Kubu Raya juga cenderung mendukung perkembangan di Kota Pontianak. Selain itu, Kota Pontianak juga merupakan Pusat Kegiatan Nasional yang yang berfungsi untuk melayani kegiatan skala internasional, nasional, atau beberapa provinsi. Kegiatan yang dimaksud adalah kegiatan ekspor dan impor atau pintu gerbang menuju kawasan internasional, kegiatan industri dan jasa serta simpul transportasi. Sehingga, kegiatankegiatan skala internasional dan nasional pada akhirnya mempunyai tujuan di Kota Pontianak setelah transit terlebih dahulu di Kubu Raya sebagai gerbang bandara internasional. Kabupaten Sintang dan Sanggau juga merupakan Kabupaten yang cukup sentral dalam konfigurasi jaringan interaksi di Kalbar. Setidaknya Sintang dan Sanggau masuk dalam skor yang cukup signifikan didalam masing-masing kategori perhitungan. Sintang dan Sanggau merupakan Kabupaten yang secara geografis terletak di tengahtengah Provinsi Kalimantan Barat, menghubungkan bagian Barat dan Timur serta UtaraSelatan sampai pada kawasan perbatasan yang berbatasan langsung dengan Sarawak, Malaysia. Selain itu, Kabupaten-Kabupaten ini mempunyai perbatasan (bagian Utara) yang dapat mengakses langsung ke negara tetangga, yaitu Sarawak, Malaysia. Setidaknya terdapat lima Kabupaten di Kalbar yang berbatasan dan dapat diakses langsung dari 
Sarawak. Hal tersebut juga membuat Sarawak menjadi salah satu wilayah (di luar Kalbar) dengan tingkat sentralitas yang signifikan di Kalbar karena kedekatan/akses tersebut.

Setelah hasil kecederungan interaksi per wilayah (by node), selanjutnya perhitungan dapat dilakukan dengan pendekatan kelompok/klaster (subgraph) wilayah yang saling berhubungan di Kalbar. Pada analisis ini, pendekatan yang digunakan adalah Clique, yang merupakan kelompok atau aktor/titik yang berinteraksi dengan lainnya dalam kedekatan tertentu sehingga membuat mereka mempunyai hubungan erat, kelompok minimum mempunyai jumlah dengan 3 anggota (Borgatti et al., 2013; Wasserman \& Faust, 1994), sebagaimana ditampilkan pada Gambar 3.

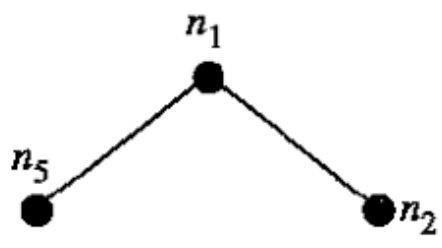

Sumber: Wasserman \& Faust, 1994

\section{Gambar 3. Ilustrasi Hubungan Clique}

Berdasarkan perhitungan atau simulasi yang dilakukan dengan UCINET, setidaknya terdapat sembilan klaster atau kelompok (subgraph) yang terbentuk. Klaster ini mengindikasikan kedekatan minimal tiga wilayah yang berinteraksi secara dekat antara satu dengan yang lain. Wilayah-wilayah yang berkelompok di antaranya, ditampilkan pada Tabel 4.

Tabel 4. Hasil Clique/ Klaster di Kalbar

\begin{tabular}{cllll}
\hline $\begin{array}{c}\text { Klaster } \\
\text { (Subgraph) }\end{array}$ & \multicolumn{1}{c}{ Wilayah 1 } & \multicolumn{1}{c}{ Wilayah 2 } & \multicolumn{1}{c}{ Wilayah 3 } & Wilayah 4 \\
\hline $\mathbf{1}$ & Kubu Raya (1) & Sanggau (1) & Sarawak (1) & Sintang (1) \\
$\mathbf{2}$ & Ketapang (1) & Kubu Raya (2) & Sanggau (2) & \\
$\mathbf{3}$ & Kapuas Hulu & Kubu Raya (3) & Sarawak (2) & Sintang (2) \\
$\mathbf{4}$ & Kubu Raya (4) & Pontianak (1) & Semarang (1) & \\
$\mathbf{5}$ & Bengkayang (1) & Landak (1) & Mempawah (1) & \\
$\mathbf{6}$ & Bengkayang (2) & Mempawah (2) & Singkawang (1) & \\
$\mathbf{7}$ & Bengkayang (3) & Sambas (1) & Sarawak (3) & \\
$\mathbf{8}$ & Bengkayang (4) & Sambas (2) & Singkawang (2) & \\
$\mathbf{9}$ & Sanggau (3) & Sekadau (1) & Sintang (3) & \\
\hline
\end{tabular}

Berdasarkan Gambar 4, dapat dilihat bagaimana struktur klaster/kelompok yang terbentuk dalam konfigurasi jaringan yang ada di Kalbar. Masing-masing wilayah berhubungan dengan wilayah terdekat lainnya sampai membentuk jaringan keseluruhan. Berdasarkan Tabel 4, terdapat 9 klaster wilayah yang berhubungan erat. Namun, apabila dilihat lebih detail mengenai skor interaksi antarwilayah, dapat dilihat bahwa wilayahwilayah dengan skor 2.000 mempunyai interaksi yang cukup dekat, di antaranya yaitu Bengkayang - Mempawah dan lanjut ke Singkawang, serta Kubu Raya - Sanggau - Sintang dan lanjut ke Sarawak. Selain itu, berdasarkan Tabel 4, dapat dilihat bahwa terdapat beberapa wilayah yang masing-masing masuk kedalam klaster lainnya (interaksi) dan mempunyai intensitas yang cukup sering, yaitu Kubu Raya dan Bengkayang. Masingmasing wilayah tersebut masuk dalam empat klaster (klaster lainnya). Juga, berdasarkan 


\section{Interaksi Antarwilayah dan Sebaran Covid-19 di Provinsi Kalimantan Barat}

dendogram pada Gambar 4, apabila dilihat dalam skala yang lebih besar, terdapat dua klaster besar yang terdiri atas wilayah-wilayah yang ditampilkan pada Tabel 5.

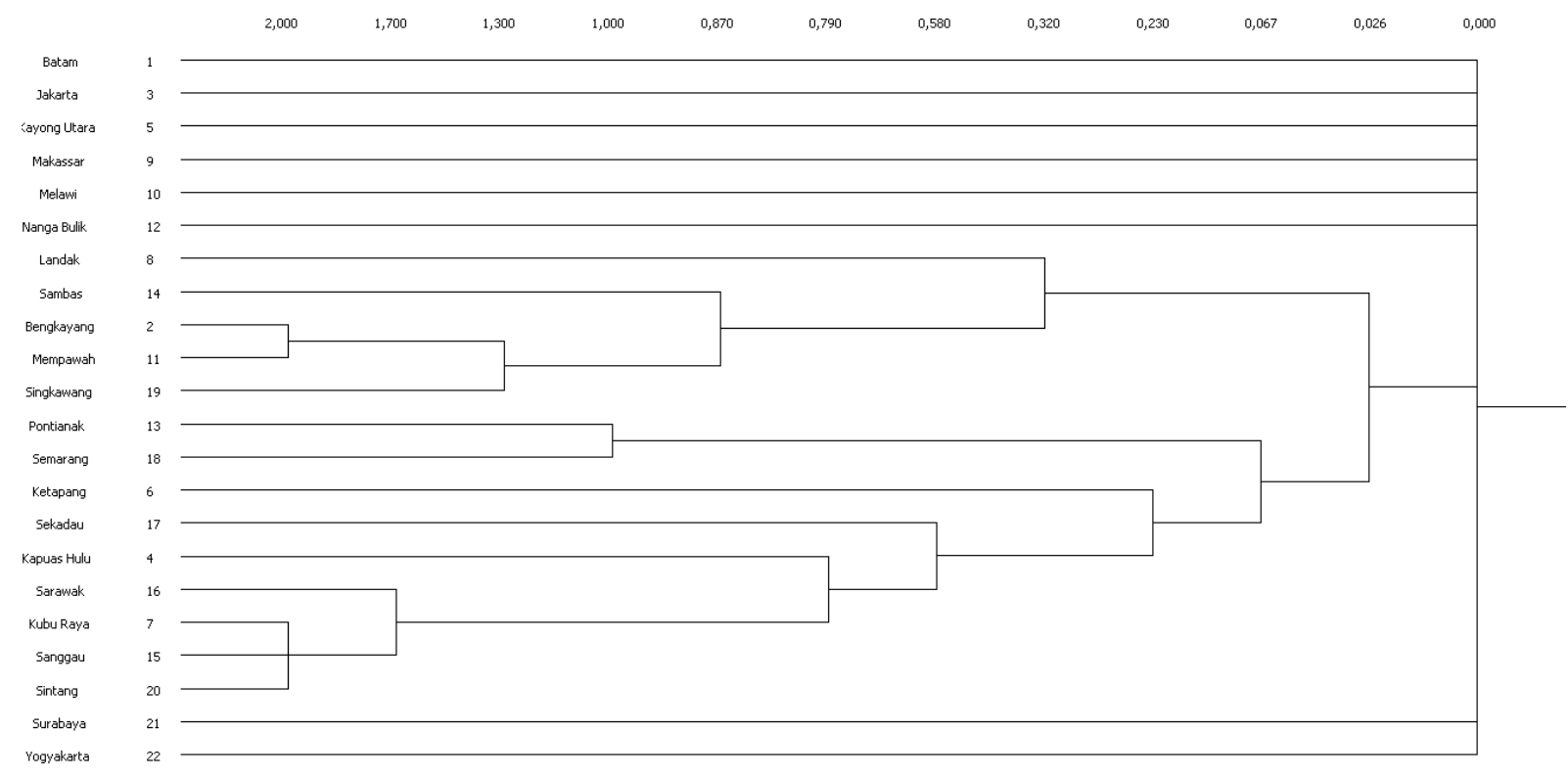

Gambar 4. Hubungan Antarwilayah

Tabel 5. Klaster Besar Wilayah di Kalbar

\begin{tabular}{lll}
\hline & Klaster Besar 1 & Klaster Besar 2 \\
\hline Bengkayang & Kubu Raya \\
Mempawah & Sanggau \\
Singkawang & Sintang \\
Sambas & Sarawak \\
Landak & Kapuas Hulu \\
& Sekadau \\
& Ketapang \\
& Pontianak \\
& Semarang \\
\hline
\end{tabular}

\section{Kecenderungan Penyebaran Covid-19 dan Interaksi Antanwilayah di Kalimantan Barat}

Dirangkum dari Dinas Kesehatan Provinsi Kalimantan Barat (2020), secara umum pada Kota/Kabupaten tertentu mempunyai kecenderungan adanya kenaikan pada pasien terkonfirmasi/ positif, maupun Orang Dalam Pengawasan (ODP), dan Pasien Dalam Pengawasan (PDP). Berdasarkan Tabel 6, dapat dilihat bahwa Kota/Kabupaten seperti Pontianak, Singkawang, Kubu Raya dan Ketapang konsisten mempunyai pasien terkonfirmasi Covid-19 tertinggi di Kalbar. Baru pada data 16 Juni beberapa wilayah seperti Landak. Melawi, dan Sintang juga mempunyai kenaikan pasien yang terkonfirmasi. Untuk ODP secara konsisten wilayah-wilayah seperti Bengkayang, Sambas, Landak, dan Ketapang mempunyai jumlah orang dengan jumlah yang cukup banyak dibandingkan dengan wilayah lain. Masing-masing wilayah tersebut mempunyai jumlah ribuan, bahkan dibandingkan dengan Pontianak yang mempunyai jumlah pasien terkonfirmasi terbanyak. Sedangkan untuk PDP, Pontianak, Singkawang, dan Kubu Raya cenderung merupakan wilayah dengan jumlah PDP terbanyak, lebih lengkapnya dapat dilihat pada Tabel 6. 


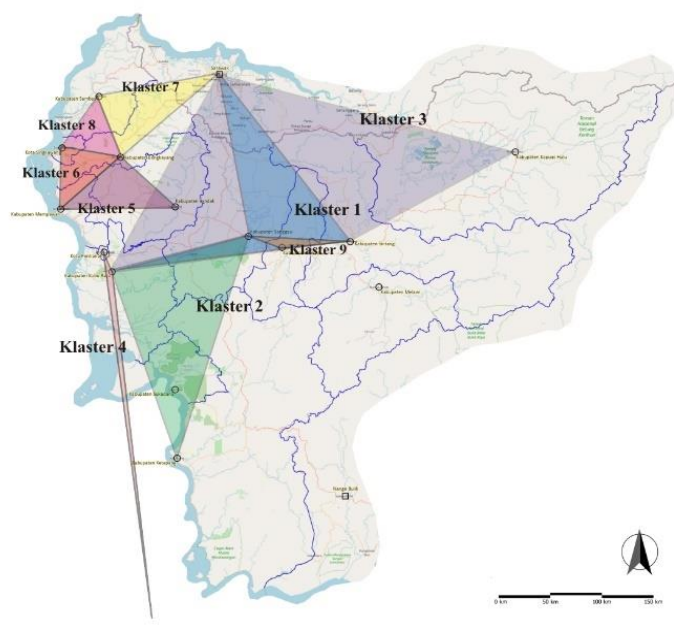

(a)

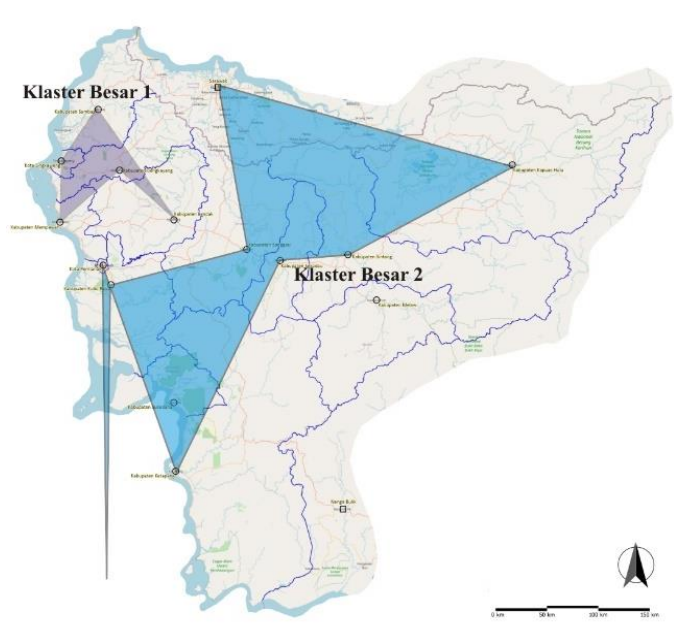

(b)

Gambar 5. Hubungan Antarwilayah dalam Klaster (a) Pembagian Clique/Klaster dan (b) Pembagian Klaster Besar

Tabel 6. Perkembangan Kasus Covid-19 di Kalbar

\begin{tabular}{|c|c|c|c|c|c|c|c|c|c|c|c|c|c|}
\hline \multirow{3}{*}{ No } & \multirow{3}{*}{$\begin{array}{c}\text { Kota/ } \\
\text { Kabupaten }\end{array}$} & \multicolumn{12}{|c|}{ Kasus Covid-19 } \\
\hline & & \multicolumn{3}{|c|}{29 Mei 2020} & \multicolumn{3}{|c|}{ 08 Juni 2020} & \multicolumn{3}{|c|}{ 16 Juni 2020} & \multicolumn{3}{|c|}{21 Juni 2020} \\
\hline & & Positif & ODP & PDP & Positif & ODP & PDP & Positif & ODP & PDP & Positif & ODP & PDP \\
\hline 1 & Pontianak & 98 & 561 & 35 & 104 & 683 & 22 & 110 & 761 & 24 & 116 & 784 & 18 \\
\hline 2 & Singkawang & 10 & 367 & 12 & 10 & 691 & 11 & 11 & 691 & 11 & 12 & 691 & 10 \\
\hline 3 & Mempawah & 5 & 284 & 5 & 6 & 284 & 3 & 5 & 284 & 5 & 5 & 284 & 6 \\
\hline 4 & Bengkayang & 3 & 1.265 & 3 & 3 & 1.908 & 5 & 5 & 1.908 & 4 & 5 & 2.189 & 4 \\
\hline 5 & Sambas & 3 & 3.840 & 5 & 3 & 3.840 & 10 & 6 & 3.840 & 4 & 6 & 3.840 & 5 \\
\hline 6 & Landak & 5 & 1.480 & 4 & 5 & 1.480 & 4 & 18 & 1.480 & 2 & 18 & 1.480 & 3 \\
\hline 7 & Sanggau & 3 & 412 & 3 & 4 & 218 & 0 & 6 & 204 & 0 & 9 & 209 & 0 \\
\hline 8 & Kubu Raya & 21 & 185 & 18 & 24 & 226 & 13 & 31 & 226 & 18 & 33 & 226 & 18 \\
\hline 9 & $\begin{array}{l}\text { Kayong } \\
\text { Utara }\end{array}$ & 2 & 164 & 0 & 3 & 176 & 0 & 3 & 178 & 1 & 3 & 190 & 2 \\
\hline 10 & Ketapang & 18 & 1.661 & 7 & 21 & 1.688 & 6 & 32 & 1.738 & 6 & 33 & 1.775 & 6 \\
\hline 11 & Sekadau & 4 & 589 & 1 & 4 & 775 & 1 & 7 & 842 & 1 & 7 & 864 & 1 \\
\hline 12 & Melawi & 1 & 227 & 1 & 7 & 227 & 0 & 12 & 227 & 0 & 12 & 227 & 0 \\
\hline 13 & Sintang & 6 & 759 & 0 & 6 & 764 & 0 & 14 & 766 & 0 & 27 & 766 & 0 \\
\hline 14 & $\begin{array}{l}\text { Kapuas } \\
\text { Hulu }\end{array}$ & 1 & 545 & 2 & 569 & 2 & 0 & 2 & 604 & 3 & 2 & 618 & 3 \\
\hline
\end{tabular}

Sumber: Dinas Kesehatan Provinsi Kalimantan Barat, 2020

Berdasarkan superimpose yang dilakukan terhadap jumlah pasien terkonfirmasi, ODP, dan PDP, serta hubungannya dengan interaksi antarwilayah dalam pembagian klaster di Kalbar, dapat dilihat bagaimana kecenderungan penyebaran Covid-19 (Gambar 6). Terkait dengan jumlah terkonfirmasi terbanyak, dapat dilihat bahwa Pontianak, Kubu Raya, dan Ketapang masing-masing dalam Klaster Besar 2 menjadi wilayah terkonfirmasi terbanyak. Dilihat dari karakteristik wilayah dalam ukuran sentralitas (Tabel 2), wilayahwilayah seperti Kubu Raya, Sanggau, dan Sintang merupakan wilayah-wilayah dengan tingkat sentralitas yang cukup tinggi di dalam konfigurasi jaringan di Kalbar. Selain itu, sebagai salah satu wilayah dalam klaster besar 2, Kubu Raya merupakan pusat dari seluruh jaringan yang ada di Kalbar apabila dilihat dari perhitungan sentralitas. Kubu Raya 


\section{Interaksi Antarwilayah dan Sebaran Covid-19 di Provinsi Kalimantan Barat}

merupakan wilayah dengan lokasi titik transportasi udara utama yang menghubungkan wilayah-wilayah di Kalbar maupun di dalam Kalbar sendiri. Pontianak menjadi wilayah dengan jumlah terkonfirmsi tertinggi dan masuk dalam klaster besar 2. Hal ini dapat di hipotesakan dikarenakan dekatnya wilayah ini dengan Kubu Raya. Selain itu, Kota Pontianak juga merupakan ibu kota Provinsi, serta tujuan utama dari para pendatang dari bandara di Kubu Raya, maupun Pelabuah Dwikora di Pontianak, karena dilengkapi dengan sarana dan prasarana yang lengkap, seperti akomodasi, dan fasilitas jasa lainnya.

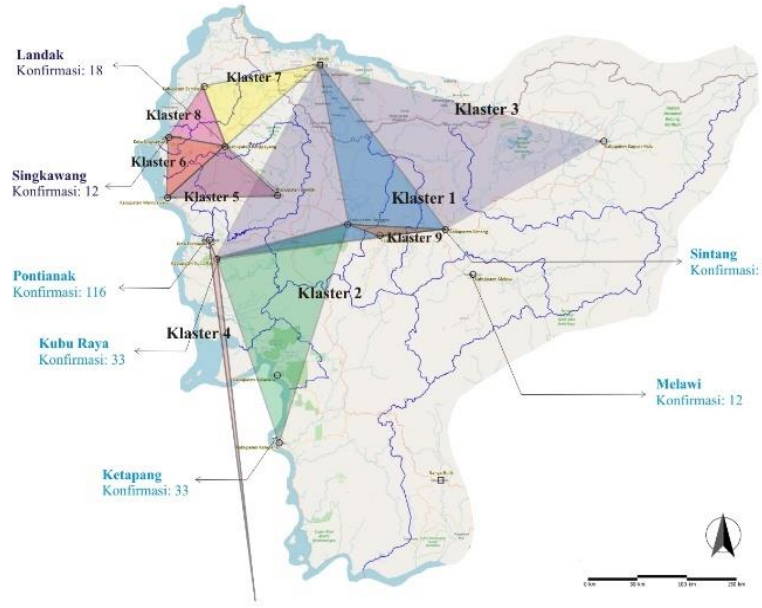

(a)

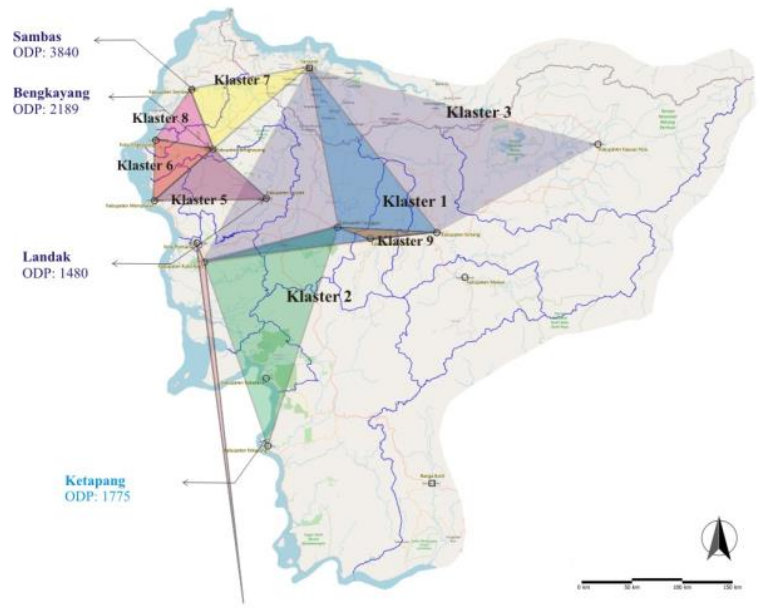

(c)

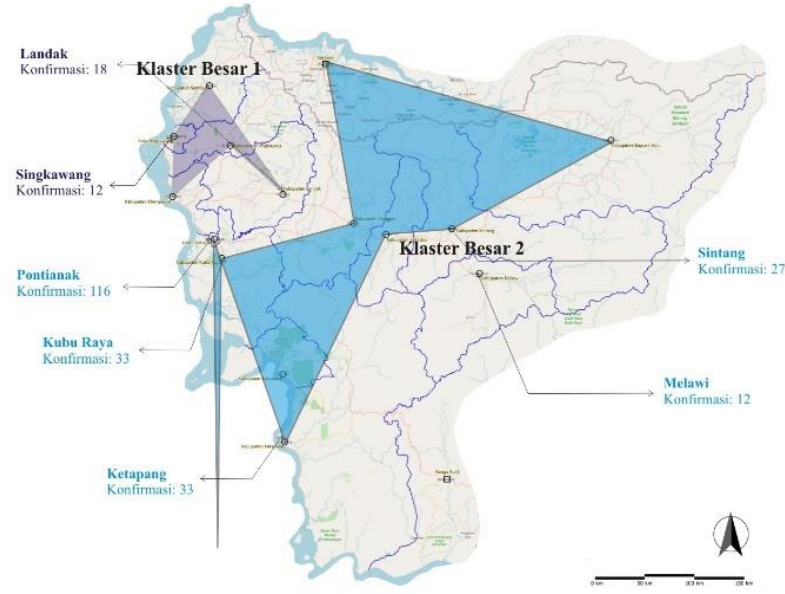

(b)

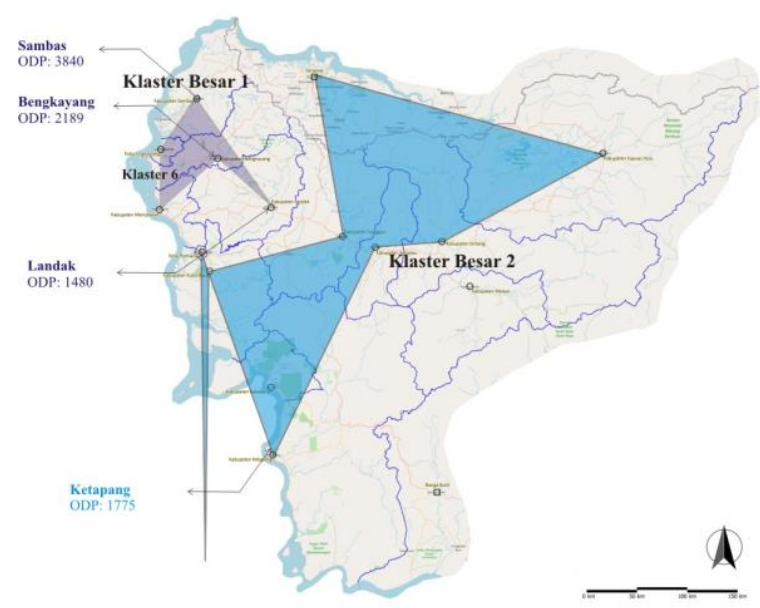

(d)

\section{Gambar 6. (a) Sebaran Kasus Terkonfirmasi dalam Clique/Klaster, (b) Sebaran Kasus Terkonfirmasi dalam Klaster Besar, (c) Sebaran Kasus ODP dalam Clique/ Klaster, dan (d) Sebaran Kasus ODP dalam Klaster Besar}

Dilihat dari kecederungan klaster besar 2 menjadi klaster terbanyak dalam kasus Covid-19 terkonfirmasi, penulis berasumsi bahwa adanya aliran-aliran mobilitas dari wilayah-wilayah sentral seperi Kubu Raya dan Pontianak sebagai wilayah dengan skor tertinggi maupun kedekatan terhadapnya. Selain itu, di bagian timur Kalbar juga terdapat Sanggau dan Sintang yang masuk dalam klaster besar 2. Dilihat dari faktor sentralitas wilayah, Sanggau dan Sintang memiliki skor yang cukup signifikan terhadap posisi sentralnya dalam konfigurasi jaringan di Kalbar. Perlu juga diketahui bahwa Kubu Raya 
mempunyai akses langsung dengan Sanggau lalu menuju ke Sintang (Gambar 2), sehingga asumsi yang dapat dibangun adalah Kubu Raya sebagai wilayah sentral memberikan pengaruh yang signifikan terhadap penyebaran Covid-19 dalam perspektif jejaring. Ditambah lokasinya yang cukup dekat dengan Kota Pontianak sebagai wilayah dengan jumlah terkonfirmasi terbanyak.

Di lain pihak, apabila melihat indikator lainnya yaitu ODP, beberapa wilayah seperti Sambas, Bengkayang, Ketapang, dan Landak mempunyai kecederungan jumlah yang cukup tinggi dibandingkan dengan wilayah lainnya. Menarik untuk diperhatikan, bahwa sebaran ODP berbanding terbalik dengan kasus terkonfirmasi yang mempunyai jumlah terbanyak di klaster besar 2. Untuk sebaran ODP, klaster besar 1 lebih dominan jumlahnya, terutama di Sambas, Bengkayang, dan Landak. Secara umum, wilayah-wilayah tersebut mempunyai nilai sentralitas (Tabel 2) yang tidak terlalu besar dibandingkan dengan wilayah lainnya di klaster besar 2, hanya Bengkayang yang mempunyai nilai degree cukup besar dibandingkan dengan wilayah lainnya, terutama di dalam interaksi di klaster besar 1. Lebih lanjut, wilayah-wilayah di klaster besar 1 cenderung berinteraksi dengan Kota Pontianak. Jalur pesisir menghubungkan wilayah-wilayah seperti Pontianak, Mempawah, Bengkayang, Singkawang, Sambas sampai ke Sarawak, Malaysia. Selain itu, wilayah-wilayah tersebut cenderung hanya berinteraksi dengan satu wilayah di luar klasternya (Gambar 2), seperti Mempawah dengan Pontianak, Bengkayang dengan Sarawak, Sambas dengan Sarawak, Landak dengan Sanggau. Namun, jalur pesisir yang ada di Kalbar selama ini mempunyai akses yang cukup baik, terutama akses darat sampai menembus Sarawak, bahkan akan dikembangkan untuk dibangun jalur tol dari Pontianak ke Singkawang untuk mendukung perekonomian masyarakat, khususnya sektor pariwisata. Selain itu, wilayah-wilayah di klaster besar 1 cenderung mempunyai jumlah kepadatan penduduk yang cukup tinggi dibandingkan dengan wilayah lain, terutama di Sambas, Bengkayang, dan Singkawang.

Berdasarkan perspektif penelitian sebelumnya serta umpan balik terhadap hasil yang didapatkan, dalam studi Inaida et al. (2011) menemukan bahwa penyebaran endemi lebih cepat terjadi pada daerah atau kawasan metropolitan dengan jumlah populasi yang besar atau padat yang diakibatkan adanya infeksi langsung antara orang per orang. Demikian pula pada hasil yang didapatkan, bahwa Kota Pontianak sebagai ibukota Provinsi (kota besar dengan populasi mencapai 500.000 ribu jiwa) mempunyai nilai pasien terkonfirmasi terbanyak. Selain itu, Kabupaten Kubu Raya yang merupakan Kabupaten terdekat dan sering dikatakan sebagai ekstensi dan pendukung Kota Pontianak, juga mempunyai jumlah pasien terkonfirmasi terbanyak. Merler \& Ajelli (2010) juga menyampaikan bahwa konfigurasi spasial dan populasi mempunyai dampak dalam penyebaran. Dalam pembahasannya, hierarki perkotaan cenderung menentukan penyebaran, contohnya kota besar menyebarkan infeksi ke kota kecil. Selain itu, beberapa unsur penentu sebaran juga ditentukan oleh heterogenitas populasi, pola-pola pergerakan masyarakat, transportasi, serta ditambahkan. Bajardi et al. (2011) menyatakan bahwa penyebaran penyakit infeksi dapat disebabkan oleh pergerakan atau mobilitas manusia. Transportasi menjadi salah satu penentu utama dalam penyebaran penyakit. Selain itu, jumlah populasi yang padat yang menyebar ke daerah tetangga juga merupakan salah satu pertimbangan penyebarannya (Dunn, 1958). Disambung oleh Valleron et al. (2010), hipotesis yang mungkin dapat dikembangkan dalam transmisi pandemik tidak hanya jumlah perjalananan atau transportasi antarkota atau wilayah, melainkan keterhubungan jaringan antar kota dan fasilitas yang menghubungkannya. Terkait dengan konektivitas, oleh Tuncer \& Le (2014) serta Grais et al. (2003), penyebaran pandemi dapat dipercepat dengan adanya akselerasi interkoneksivitas antarwilayah atau kota melalui transportasi (udara). Lanjut mereka, apabila kota atau daerah saling berhubungan maka perubahan-perubahan reproduksi terhadap penyebaran antara daerah asal dan daerah tujuan dapat lebih efektif. 


\section{Interaksi Antarwilayah dan Sebaran Covid-19 di Provinsi Kalimantan Barat}

Berdasarkan perspektif tersebut, ditemukan bahwa beberapa aspek seperti konektivitas antarwilayah dapat menjadi salah satu pertimbangan dalam penyebaran penyakit. Hierarki kota dengan jumlah penduduk yang tinggi juga menjadi alasan bagaimana penyakit dapat dengan cepat menyebar. Dilihat dari beberapa korelasi dari temuan penelitian, wilayah-wilayah dengan tingkat sentralitas yang mempunyai konektivitas paling tinggi seperti Kubu Raya, Sanggau, Sintang, masing-masing cenderung mempunyai kasus Covid-19 yang cukup tinggi, khususnya Kubu Raya sebagai pintu masuk utama ke Kalbar melalui udara. Selain itu, wilayah-wilayah tersebut juga masuk dalam klaster besar 2 (Gambar 5) yang berhubungan dengan wilayah lainnya yang terhubung dengan kasus Covid-19 yang cukup tinggi, seperti Pontianak dan Ketapang. Untuk diketahui bahwa Kota Pontianak merupakan ibukota Provinsi dan mempunyai perbatasan langsung dengan Kubu Raya. Yang menarik adalah wilayah-wilayah di klaster besar 1 yang berada di pesisir Kalbar cenderung mempunyai nilai ODP yang sangat besar dibanding dengan yang lainnya. Dilihat dari kecederungan nilai sentralitas, wilayah-wilayah tersebut tidak terlalu mempunyai nilai yang signifikan namun berhubungan langsung dengan Pontianak dan Sarawak sebagai salah satu pusat kegiatan nasional serta negara tetangga yang mempunyai kasus terkonfiramsi Covid-19 sebanyak 569 per 23 Juni 2020. Selain itu, kabupaten-kabupaten di pesisir Kalbar tersebut mempunyai kepadatan penduduk yang cukup tinggi dibandingkan dengan wilayah di bagian Timur Kalbar. Arahan yang didapatkan adalah secara umum beberapa penelitian sebelumnya telah menegaskan beberapa aspek pertimbangan terhadap interaksi wilayah dan penyebaran penyakit (pandemi). Hasil penelitian dalam artikel ini memberikan kontribusi, gambaran, dan diskusi akademik bagaimana wilayah-wilayah yang utama atau sentral serta hubungannya dengan wilayah lain dalam konfigurasi jaringan memberikan pengaruh dalam penyebaran penyakit.

\section{Kesimpulan}

Kontribusi dari temuan hasil penelitian ini adalah menggambarkan bagaimana interaksi wilayah di Kalbar dan kaitannya dengan penyebaran pandemik Covid-19. Dari temuan, didapati beberapa hal yaitu wilayah dengan sentralitas tinggi dan merupakan pintu masuk/kota besar (dalam konteks populasi dan kemudahan transportasi) mempunyai kecenderungan kasus terkonfirmasi terbanyak. Wilayah-wilayah dengan tingkat sentralitas tinggi dalam konfigurasi jaringan di Kalbar cenderung mempunyai kasus/pasien terkonfirmasi terbanyak dibandingkan dengan wilayah lain. Karakter wilayah-wilayah tersebut cenderung merupakan pintu utama (udara), Ibukota provinsi, serta wilayahwilayah hub atau penghubung di bagian Timur Kalbar yang juga merupakan dalam satu kesatuan klaster. Dalam hal kasus terkonfirmasi, Kota Pontianak merupakan wilayah dengan kasus terbanyak. Secara karakteristik, Pontianak merupakan Ibukota Provinsi dan merupakan daerah tujuan utama yang dilengkapi dengan sarana dan prasarana yang baik. Selain itu, jarak ke bandar udara (Kubu Raya) juga cukup dekat. Hal yang menarik lainnya adalah wilayah-wilayah dengan nilai atau skor rendah dalam sentralitasnya, serta masuk dalam klaster yang sama mempunyai jumlah ODP yang cukup besar dibandingkan dengan klaster sebelumnya. Wilayah-wilayah ini seperti Sambas, Bengkayang, Landak. Wilayahwilayah ini cenderung mempunyai populasi yang padat serta Kabupaten Sambas berhubungan langsung dengan Sarawak dan mempunyai jalur langsung ke Ibukota Provinsi. Kontribusi lain dalam penelitian ini adalah memberikan pandangan baru dalam perencanaan atau pengembangan wilayah (analisis jaringan) bahwa terdapat implikasi dari sebuah sentralitas wilayah, dengan munculnya kemudahan-kemudahan terhadap penyebaran penyakit. Keterbatasan pada hasil penelitian ini adalah jumlah/perkembangan kasus yang digunakan merujuk pada data 1 bulan terakhir. Pada perkembangannya, kasus 
akan terus berfluktuatif dan bisa saja berubah pada bulan-bulan berikutnya. Untuk itu, penelitian lanjutan dapat dilakukan dengan melihat data yang cukup komprehensif.

\section{Ucapan Terima Kasih}

Artikel ini merupakan Hasil dari Hibah Penelitian Dasar 2020 (refocusing Covid-19) yang dibiayai oleh Kemenristek/BRIN.

\section{Daftar Pustaka}

Bajardi, P., Poletto, C., Ramasco, J. J., Tizzoni, M., Colizza, V., \& Vespignani, A. (2011). Human mobility networks, travel restrictions, and the global spread of $2009 \mathrm{H} 1 \mathrm{~N} 1$ pandemic. PLOS ONE, 6(1), 1-8. doi:10.1371/journal.pone.0016591.

Borgatti, S. (1995). Centrality and AIDS. Connections, 18(1), 111-113.

Borgatti, S. P., Everett, M. G., \& Freeman, L. C. (2002). UCINET for windows: Software for social network analysis. Harvard, MA.

Borgatti, S. P., Everett, M. G., \& Johnson, J. C. (2013). Analyzing social networks (First Edit). California: SAGE Publications Ltd.

Chen, N., Zhou, M., Dong, X., Qu, J., Gong, F., Han, Y., ... Zhang, L. (2020). Epidemiological and clinical characteristics of 99 cases of 2019 novel coronavirus pneumonia in Wuhan, China: a descriptive study. The Lancet, 395(10223), 507-513. doi:10.1016/S0140-6736(20)30211-7.

Dinas Kesehatan Provinsi Kalimantan Barat. (2020). Jumlah terpapar Covid-19 di Kalimantan Barat. Retrieved from https://dinkes.kalbarprov.go.id/covid-19/.

Downs, J. A., \& Horner, M. W. (2012). Probabilistic potential path trees for visualizing and analyzing vehicle tracking data. Journal of Transport Geography, 23, 72-80. doi:10.1016/j.jtrangeo.2012.03.017.

Dunn, F. L. (1958). Pandemic influenza in 1957: Review of international spread of new asian strain. Journal of the American Medical Association, 166(10), 1140-1148. doi:10.1001/jama.1958.02990100028006.

Edmonds, E. A. (2007). Reflections on the nature of interaction. CoDesign International Journal of CoCreation in Design and the Arts, 3(3), 139-143. doi:10.1080/15710880701251427.

Glasson, J., \& Marshall, T. (2007). Regional planning. Abingdon-on-Thames: Routledge.

Grais, R. F., Ellis, J. H., \& Glass, G. E. (2003). Assessing the impact of airline travel on the geographic spread of pandemic influenza. European Journal of Epidemiology, 18(11), 1065-1072. doi:10.1023/a:1026140019146.

Guan, W., Ni, Z., Hu, Y., Liang, W., Ou, C., He, J., ... Zhong, N. (2020). Clinical characteristics of coronavirus disease 2019 in China. New England Journal of Medicine, 382(18), 1708-1720. doi:10.1056/NEJMoa2002032.

Hanneman, R. A., \& Riddle, M. (2005). Introduction to social network methods. Riverside, CA: University of California, Riverside. Retrieved from http://faculty.ucr.edu/ hanneman/.

Huang, C., Wang, Y., Li, X., Ren, L., Zhao, J., Hu, Y., ... Cao, B. (2020). Clinical features of patients infected with 2019 novel coronavirus in Wuhan, China. The Lancet, 395(10223), 497-506. doi:10.1016/S01406736(20)30183-5.

Inaida, S., Yasui, Y., Tada, Y., Taniguchi, K., \& Okabe, N. (2011). Geographic trends and spread of the pandemic (H1N1) 2009 in the metropolitan areas of Japan studied from the national sentinel data. Japanese Journal of Infectious Diseases, 64(6), 473-481.

Kadi, N., \& Khelfaoui, M. (2020). Population density, a factor in the spread of COVID-19 in Algeria: statistic study. Bulletin of the National Research Centre, 44(1), 138. doi:10.1186/s42269-020-00393-x.

Kang, D., Choi, H., Kim, J.-H., \& Choi, J. (2020). Spatial epidemic dynamics of the COVID-19 outbreak in China. International Journal of Infectious Diseases, 94, 96-102. doi:10.1016/j.ijid.2020.03.076.

Kubota, Y., Shiono, T., Kusumoto, B., \& Fujinuma, J. (2020). Multiple drivers of the COVID-19 spread: The roles of climate, international mobility, and region-specific conditions. PLOS ONE, 15(9), 1-15. 


\section{Interaksi Antarwilayah dan Sebaran Covid-19 di Provinsi Kalimantan Barat}

doi:10.1371/journal.pone.0239385.

Lau, H., Khosrawipour, V., Kocbach, P., Mikolajczyk, A., Ichii, H., Zacharski, M., ... Khosrawipour, T. (2020). The association between international and domestic air traffic and the coronavirus (COVID-19) outbreak. Journal of Microbiology, Immunology and Infection, 53(3), 467-472. doi:10.1016/j.jmii.2020.03.026.

Lawyer, G. (2016). Measuring the potential of individual airports for pandemic spread over the world airline network. BMC Infectious Diseases, 16(1), 70. https://doi.org/10.1186/s12879-016-1350-4

Li, Q., Guan, X., Wu, P., Wang, X., Zhou, L., Tong, Y., ... Feng, Z. (2020). Early transmission dynamics in Wuhan, China, of novel coronavirus-infected pneumonia. New England Journal of Medicine, 382(13), 1199-1207. doi:10.1056/NEJMoa2001316.

Lobo-Guerrero, L. (2012). Connectivity as the strategization of space - the case of the Port of Hamburg. Distinktion: Scandinavian Journal OfSocial Theory, 13(3), 310-321. doi:10.1080/1600910X.2012.697860.

Merler, S., \& Ajelli, M. (2010). The role of population heterogeneity and human mobility in the spread of pandemic influenza. Proceedings. Biological Sciences, 277(1681), 557-565. doi:10.1098/rspb.2009.1605.

Pemerintah Provinsi Kalimantan Barat. (2020). Satu data Kalbar. Retrieved from http://data.kalbarprov.go.id.

Ratcliffe, R. (2020). First coronavirus cases confirmed in Indonesia amid fears nation is ill-prepared for an outbreak. The Guardian. Retrieved from https://www.theguardian.com/world/2020/mar/02/firstcoronavirus-cases-confirmed-in-indonesia-amid-fears-nation-is-ill-prepared-for-outbreak.

Reuters. (2020). Indonesia confirms first cases of coronavirus. Bangkok Post. Retrieved from https://www.bangkokpost.com/world/1869789/indonesia-confirms-first-cases-of-coronavirus.

Scott, N., Baggio, R., \& Cooper, C. (2008). Network analysis and tourism: From theory to practice. UK, US, Canada: Channel View Publications.

Sokol, M. (2009). Regional connectivity. In R. Kitchin \& N. Thrift (Eds.), International Encyclopedia of Human Geography. Oxford, UK: Elsevier.

Staeheli, U. (2012). Listing the global: dis/connectivity beyond representation? Distinktion: Journal of Social Theory, 13(3), 233-246. doi:10.1080/1600910X.2012.724646.

Tuncer, N., \& Le, T. (2014). Effect of air travel on the spread of an avian influenza pandemic to the United States. International Journal of Critical Infrastructure Protection, 71), 27-47. doi:10.1016/j.ijcip.2014.02.001.

Valleron, A.-J., Cori, A., Valtat, S., Meurisse, S., Carrat, F., \& Boëlle, P.-Y. (2010). Transmissibility and geographic spread of the 1889 influenza pandemic. Proceedings of the National Academy of Sciences of the United States of America, 10719), 8778-8781. doi:10.1073/pnas.1000886107.

Vega, A. (2012). Accessibility and the local concentration of economic activity: A case study for county Galway. Irish Geography, 45(1), 25-44. doi:10.1080/00750778.2012.729917.

Wang, C., Horby, P. W., Hayden, F. G., \& Gao, G. F. (2020). A novel coronavirus outbreak of global health concern. The Lancet, 395(10223), 470-473. doi:10.1016/S0140-6736(20)30185-9.

Wasserman, S., \& Faust, K. (1994). Social network analysis: Methods and applications. Cambridge: Cambridge University Press.

Xie, Z., Qin, Y., Li, Y., Shen, W., Zheng, Z., \& Liu, S. (2020). Spatial and temporal differentiation of COVID-19 epidemic spread in mainland China and its influencing factors. Science of The Total Environment, 744, 140929. doi:10.1016/j.scitotenv.2020.140929.

Zhao, S., \& Chen, H. (2020). Modeling the epidemic dynamics and control of COVID-19 outbreak in China. Quantitative Biology, 8(1), 11-19. doi:10.1007/s40484-020-0199-0. 